\title{
Deletion of the hemopexin or heme oxygenase-2 gene aggravates brain injury following stroma-free hemoglobin-induced intracerebral hemorrhage
}

\author{
Bo Ma', Jason Patrick Day ${ }^{1}$, Harrison Phillips ${ }^{1}$, Bryan Slootsky ${ }^{1}$, Emanuela Tolosano ${ }^{2}$ and Sylvain Doré ${ }^{1,3^{*}}$
}

\begin{abstract}
Background: Following intracerebral hemorrhage $(\mathrm{ICH})$, red blood cells release massive amounts of toxic heme that causes local brain injury. Hemopexin ( $\mathrm{Hpx}$ ) has the highest binding affinity to heme and participates in its transport, while heme oxygenase $2\left(\mathrm{HO}_{2}\right)$ is the rate-limiting enzyme for the degradation of heme. Microglia are the resident macrophages in the brain; however, the significance and role of $\mathrm{HO} 2$ and $\mathrm{Hpx}$ on microglial clearance of the toxic heme (iron-protoporphyrin IX) after ICH still remain understudied. Accordingly, we postulated that global deletion of constitutive $\mathrm{HO} 2$ or Hpx would lead to worsening of ICH outcomes.

Methods: Intracerebral injection of stroma-free hemoglobin (SFHb) was used in our study to induce ICH. Hpx knockout $\left(\mathrm{Hpx}^{-/-}\right)$or $\mathrm{HO} 2$ knockout $\left(\mathrm{HO}^{-/-}\right)$mice were injected with $10 \mu \mathrm{L}$ of SFHb in the striatum. After injection, behavioral/functional tests were performed, along with anatomical analyses. Iron deposition and neuronal degeneration were depicted by Perls' and Fluoro-Jade B staining, respectively. Immunohistochemistry with anti-ionized calcium-binding adapter protein 1 (Iba1) was used to estimate activated microglial cells around the injured site.

Results: This study shows that deleting Hpx or $\mathrm{HO} 2$ aggravated SFHb-induced brain injury. Compared to wild-type littermates, larger lesion volumes were observed in $\mathrm{Hpx}^{-1-}$ and $\mathrm{HO}^{-1-}$ mice, which also bear more degenerating neurons in the peri-lesion area $24 \mathrm{~h}$ postinjection. Fewer Iba1-positive microglial cells were detected at the peri-lesion area in $\mathrm{Hpx}^{-/-}$and $\mathrm{HO}^{-/-}$mice, interestingly, which is associated with markedly increased iron-positive microglial cells. Moreover, the Iba1-positive microglial cells increased from 24 to $72 \mathrm{~h}$ postinjection and were accompanied with improved neurologic deficits in $\mathrm{Hpx}^{-/-}$and $\mathrm{HO}^{-/-}$mice. These results suggest that Iba1-positive microglial cells could engulf the extracellular SFHb and provide protective effects after $\mathrm{ICH}$. We then treated cultured primary microglial cells with SFHb at low and high concentrations. The results show that microglial cells actively take up the extracellular SFHb. Of interest, we also found that iron overload in microglia significantly reduces the Iba1 expression level and resultantly inhibits microglial phagocytosis.
\end{abstract}

Conclusions: This study suggests that microglial cells contribute to hemoglobin-heme clearance after ICH; however, the resultant iron overloads in microglia appear to decrease Iba1 expression and to further inhibit microglial phagocytosis.

Keywords: Fluoro-Jade, Hemorrhagic stroke, Iron, Microglia, Perls, Phagocytosis

\footnotetext{
*Correspondence: sdore@ufl.edu

'Department of Anesthesiology, Center for Translational Research in

Neurodegenerative Disease, University of Florida College of Medicine, P.O.

Box 100159, Gainesville, FL 32610, USA

${ }^{3}$ Departments of Neuroscience, Neurology, Psychiatry, Psychology and

Pharmaceutics, University of Florida College of Medicine, Gainesville, FL

32610, USA

Full list of author information is available at the end of the article
} 


\section{Background}

Intracerebral hemorrhage $(\mathrm{ICH})$ causes severe clinical disability and mortality [1]. During $\mathrm{ICH}$, large amounts of erythrocytes are released into the extracellular spaces in the brain. When erythrocytes are lysed, extracellular hemoglobin is rapidly oxidized from ferrous $\left(\mathrm{Fe}^{2+}\right)$ to ferric $\left(\mathrm{Fe}^{3+}\right)$ hemoglobin (methemoglobin) [2, 3], which, in turn, readily releases heme $[4,5]$. The free heme is extremely lipophilic and binds to lipids intercalating into cell membranes, which results in cellular oxidative damage $[6,7]$. Understanding how the released heme is removed after $\mathrm{ICH}$ is important because excess free heme is highly toxic [8-11]. The hemoglobin and heme scavenger proteins haptoglobin $(\mathrm{Hp})$ and hemopexin $(\mathrm{Hpx})$ contribute to hematoma removal after $\mathrm{ICH}$ [12], and $\mathrm{Hpx}$ has the highest binding affinity to heme $(\mathrm{Kd}<$ 1 pM) $[12,13]$. Hp and Hpx have been characterized as a sequential defense system with $\mathrm{Hp}$ as the primary protector and Hpx as a backup when $\mathrm{Hp}$ has been depleted during severe $\mathrm{ICH}$. Interestingly, recent quantitative analysis defined an exponential relationship between $\mathrm{Hp}$ availability relative to hemoglobin and related protective activities, illustrating that large $\mathrm{Hp}$ quantities are required to prevent hemoglobin toxicity [14], perhaps because oxidatively modified hemoglobin loses its binding affinity to Hp and CD163 [15]. In contrast, the linear relationship between $\mathrm{Hpx}$ concentration and protection defined a highly efficient backup scavenger system during conditions of large excess of free hemoglobin [14]. These together suggest that Hpx could be more critical in hematoma removal after ICH than has been known before. One study also supports that another role of $\mathrm{Hpx}$ is to act as an antioxidant after blood-heme overload [16]. The heme-Hpx complex is endocytosed by cells expressing the CD91 receptor [17]. It is noteworthy that the CD91 receptor is highly expressed within the brain on vascular cells, microglia, and neurons [18]. The CD163 receptor is known for the uptake of the Hphemoglobin complex and is expressed on activated microglia [19]. In the brain, $\mathrm{Hp}$ is almost exclusively synthesized by oligodendrocytes [20], and Hpx is expressed on neurons and microglia [21-23]. Moreover, it has been suggested that $\mathrm{Hp}$ expression cannot be induced in the brain. For example, intraperitoneal injection of bacterial endotoxin has been shown to cause a robust increase in $\mathrm{Hp}$ expression in peripheral organs and blood serum, but not in the brain [15].

The heme oxygenase ( $\mathrm{HO})$ system is responsible for cellular heme degradation to biliverdin, iron, and carbon monoxide. Two main isoforms have been reported to date: homologous $\mathrm{HO} 1$ and $\mathrm{HO} 2$ are microsomal proteins that share more than $45 \%$ residue identity and catalyze the same reaction. However, the HO1 isoform has been extensively studied mainly for its ability to respond to numerous cellular stresses such as oxidants, hemorrhage, or trauma [24-26]. On the contrary, HO2 has been less studied likely due to its apparent constitutive nature. Nevertheless, its particular abundance in the brain emphasizes the relevance of $\mathrm{HO} 2$ function [27, 28]. HO2 is constitutively expressed by most brain cells, notably neurons, and endothelial and glial cells [29-31] and accounts for the majority of $\mathrm{HO}$ activity in the brain [32]. Under oxidative stress conditions, HO2 can rapidly degrade heme [33, 34]. Further evidence for this concept came from experiments with $\mathrm{HO} 2$-deficient animals, demonstrating its involvement in brain cell damage produced by cerebral ischemia and $\mathrm{ICH}[35,36]$. HO2 is the abundant isoform in the adult rodent brain and has been detected in the forebrain, hippocampus, midbrain, basal ganglia, thalamic regions, cerebellum, and brain stem [37]. Additional effort is required to further clarify the physiological role of the $\mathrm{Hpx}-\mathrm{HO}$ system in the brain. Also, it remains to be investigated which cell type plays the major role in hemoglobin clearance after $\mathrm{ICH}$.

As the resident macrophages in the brain, microglial cells are purported effectors of the innate response after injuries. Growing evidence suggests a protective role for microglial activation in central nervous system pathologies, including $\mathrm{ICH}$ [38-41]. The possible mechanism underlying the beneficial effects of activated/migrating microglia may be phagocytosis. For example, it has been shown that microglial cells were activated and recruited to newly formed $\beta$-amyloid plaques within 1 to 2 days in animal models of Alzheimer's disease [42]. By stimulating the peroxisome proliferator-activated receptor, it has been demonstrated that activated microglia can promote the removal of hematomas after ICH [38]. Even in the resting state, microglial cells can be active and vigilant in the adult brain, and blood-brain barrier disruption provokes immediate activation of microglia [43].

In general, although $\mathrm{Hpx}$ and $\mathrm{HO} 2$ are important for the clearance of hemoglobin and heme, little is known about the role that the $\mathrm{Hpx}-\mathrm{HO}$ system plays after $\mathrm{ICH}$ and notably in respect of the microglia phagocytosis properties. In this study, we investigated the role of Hpx and $\mathrm{HO} 2$ after $\mathrm{ICH}$, using genetically modified mice that have separate deletions for $\mathrm{Hpx}$ and $\mathrm{HO} 2$, to establish whether $\mathrm{Hpx}$ is a critical factor for hematoma removal after $\mathrm{ICH}$ and whether $\mathrm{HO} 2$ is required for the removal. We also investigated the unique role of microglia in hematoma removal.

\section{Methods}

\section{Animals}

All procedures were approved by the Institutional Animal Care and Use Committee of the University of Florida. Adult male Hpx knockout $\left(\mathrm{Hpx}^{-/-}\right)$mice $(22-28 \mathrm{~g})$ were descendants of those generated by Dr. Tolosano's 
lab [44], and $\mathrm{HO} 2$ knockout $\left(\mathrm{HO}^{-/-}\right)$mice were generated by Drs. Poss and Tonegawa [45]. The mouse genotype was assayed by polymerase chain reaction and was additionally confirmed by standard Western blot analysis. $\mathrm{Hpx}^{-1-}$ and $\mathrm{HO}^{-1-}$ mice were backcrossed into the C57BL/6 background, and matched C57BL/6 mice were used as the wild-type (WT) controls. The knockout mice and the size of their litters were normal overall. No cognition or motor dysfunction was observed. When we examined the gross superficial cerebrovascular anatomy, no detectable changes were observed. Mice had access to food and water ad libitum and were housed under controlled conditions $\left(23 \pm 2{ }^{\circ} \mathrm{C} ; \quad 12\right.$-h light/dark periods).

\section{Antibodies}

The antibodies used for these studies included mouse monoclonal neuronal nuclei (NeuN; specific for neurons) antibody (Millipore, Billerica, MA), rabbit polyclonal ionized calcium-binding adapter protein 1 (Iba1) antibody (specific for microglial-like cells; Wako Bioproducts, Richmond, VA), and glial fibrillary acidic protein (GFAP) antibody (specific for astrocytic-like cells; DAKO, Carpinteria, CA). Secondary antibodies were conjugated with Alexa-488 (Jackson ImmunoResearch, Inc., West Grove, PA) or labeled with avidin-peroxidasebiotin complex (Vector Laboratories, Inc., Burlingame, CA).

\section{ICH model}

The procedure for preparing murine stroma-free hemoglobin (SFHb) has been described previously [46]. In brief, blood was taken by cardiac puncture in mice. After centrifugation (2500 r.p.m.) for $5 \mathrm{~min}$ at $4{ }^{\circ} \mathrm{C}$, the supernatant was removed and the cell pellet was washed three times with sterile saline. Cells were then collected, suspended in sterile saline, and lysed by two freeze-thaw cycles. The sample was then centrifuged, the supernatant was removed, and the hemoglobin concentration was determined spectrophotometrically. SFHb was then diluted with sterile saline to $2 \mathrm{mM}$ (expressed as the concentration of the hemoglobin tetramer), which approximates its concentration in whole blood. It was aliquoted and stored at $-80{ }^{\circ} \mathrm{C}$ until used. For hemoglobin injection, age- and weight-matched male mice were anesthetized with halothane (3\% initial, $1-1.5 \%$ maintenance) in $\mathrm{O}_{2}$ and air (80 and $20 \%$, respectively). To model hemorrhage, we placed mice in a stereotaxic device (Stoelting, Wood Dale, IL) and introduced a 32-gauge stainless-steel needle through a burr hole into the right striatum at the following stereotactic coordinates: $0.5 \mathrm{~mm}$ anterior and $2.0 \mathrm{~mm}$ lateral of the bregma, $3.5 \mathrm{~mm}$ in depth. We then injected them unilaterally with $10 \mu \mathrm{L}$ of $2 \mathrm{mM}$ SFHb over a period of 30 min with a microinfusion apparatus. The injection needle was slowly withdrawn 15 min later, and the wound was sutured. Mice in the sham group received sterile saline injection only. Rectal temperature was maintained at $37.0 \pm 0.5{ }^{\circ} \mathrm{C}$ throughout the experimental and recovery periods. At 24 and $72 \mathrm{~h}$ after SFHb injection, behavioral tests were performed and brains were harvested for stroke injury analysis.

\section{Locomotor activity}

Locomotor activities were assessed before ICH and 24, 48 , and $72 \mathrm{~h}$ after ICH by an automated system (MED Associates, Inc., St. Albans, VT). The mice were placed in four transparent acrylic cages at the same time every day and monitored for locomotor (horizontal activity), rearing (vertical activity), and stereotypy behaviors during a 30-min test period. The results are expressed as an activity ratio of the baseline for each mouse [47].

\section{Neurological scoring}

Neurological deficits were assessed at 24 and $72 \mathrm{~h}$ after $\mathrm{SFHb}$ injection. An experimenter blind to the mouse genotype scored all mice for neurological deficits with a 24-point neurological scoring system [48]. The tests included body symmetry, gait, climbing, circling behavior, front-limb symmetry, and compulsory circling and whisker response. Each test was graded from 0 to 4, establishing a maximum deficit score of 24 . Immediately after the testing, the mice were sacrificed for injury analysis.

\section{Histology and immunohistochemistry}

At 24 and $72 \mathrm{~h}$ after $\mathrm{ICH}$, mice were euthanized and perfused transcardially with phosphate-buffered saline (PBS; pH 7.4) and then ice-cold $4 \%$ paraformaldehyde (PFA) in PBS. The brains were removed, postfixed, and cut into $30-\mu \mathrm{m}$ coronal sections with a cryostat. The mounted sections were stained with cresyl violet to estimate the lesion volume. Six to eight coronal sections, including the entire injured hemorrhagic area, were summed, and the lesion volumes in cubic millimeters were calculated by multiplying the thickness with the measured areas [47]. All slides were scanned using ScanScope CS (Aperio Technologies, Inc., Vista, CA) and analyzed using ImageScope software (Aperio Technologies, Inc.). For immunohistochemistry, free-floating sections or primary microglial cells were rinsed in PBS after fixation and permeabilization and then incubated at room temperature in $5 \%$ donkey or goat serum to block nonspecific binding. All primary antibodies were diluted in PBS and applied overnight at $4{ }^{\circ} \mathrm{C}$. Antibody concentrations were as follows: rabbit anti-Iba1: 1:1000; rabbit anti-GFAP: 1:2000; mouse anti-NeuN: 1:500. Avidinperoxidase-labeled biotin-complex secondary antibodies (1:1000) and Vectastain ABC and 3,3'-diaminobenzidine (DAB) SK-4100 kits (Vector Laboratories, Inc.) were 
then used according to the manufacturer's instructions. When followed with fluorescence staining, the sections were incubated with a secondary antibody conjugated with Alexa-488 (1:1000). After being rinsed, all sections were mounted in DAPI Hardest Reagent (Vector Laboratories, Inc.) under a glass coverslip. To use as negative controls, additional sections were incubated without the primary antibodies. Stained sections were examined with a Nikon TE2000-E Eclipse fluorescence microscope (Nikon Instruments, Inc., Melville, NY); the images were captured and analyzed by SPOT advanced image software (Diagnostic Instruments, Inc., Sterling Heights, MI). To quantify the numbers of positive cells, photos were taken of four regions of interest in each section containing the infarct sites.

\section{Perls' iron and Fluoro-Jade B staining}

Iron deposition was detected with Perls' staining for mainly nonheme ferric iron $\left(\mathrm{Fe}^{3+}\right)$ followed by DAB development. Briefly, brain sections or primary microglial cells were washed in PBS after fixation in $4 \%$ PFA and then incubated with Perls' solution (10\% potassium ferrocyanide and $20 \% \mathrm{HCl}$, equal parts in PBS) for $30 \mathrm{~min}$. After washing in PBS, the sections or microglial cells were incubated with $\mathrm{DAB}$ and hydrogen peroxide for $5 \mathrm{~min}$. Brain sections were finally counterstained with hematoxylin for 2 min. The DAB intensification and hematoxylin counterstaining were omitted when brain sections were costained with specific cellular markers.

To determine neuronal cell degeneration in brain tissue, Fluoro-Jade B staining was used according to published protocol [49]. In brief, the slides were first immersed in a solution containing $1 \%$ sodium hydroxide in $80 \%$ alcohol for $5 \mathrm{~min}$. This was followed by $2 \mathrm{~min}$ in $70 \%$ alcohol and $2 \mathrm{~min}$ in distilled water. The slides were then transferred to a solution of $0.06 \%$ potassium permanganate for $10 \mathrm{~min}$ and then rinsed in distilled water for $2 \mathrm{~min}$. The staining solution was prepared from a $0.01 \%$ stock solution of Fluoro-Jade B (Histo-Chem, Inc., Jefferson, AR). After $20 \mathrm{~min}$ in the staining solution, the slides were washed in distilled water. The dry slides were then cleared by xylene before coverslipping.

Perls' iron and Fluoro-Jade B-positive cells were counted in three to four fields immediately adjacent to the hematoma in each section. At least three sections per animal over a magnification field of $\times 400$ were averaged and expressed as cells per field. The images of stained sections were captured and analyzed by SPOT image software. Tissue sections were all processed and analyzed by an observer who was blind to the mouse genotype.

\section{Primary microglial cell cultures}

Primary microglial cultures were prepared as described previously [50]. In brief, the mixed cell culture was prepared from postnatal 2- to 4-day-old mice and then maintained at $37{ }^{\circ} \mathrm{C}$ and $5 \% \mathrm{CO}_{2}$ for 10 to 15 days in Dulbecco's modified Eagle's medium (DMEM) containing $10 \%$ heat-inactivated fetal bovine serum (FBS), $50 \mathrm{U} / \mathrm{mL}$ penicillin, and $50 \mu \mathrm{g} / \mathrm{mL}$ streptomycin. Microglial cells were collected as floating cells by gentle shaking and used for the following experiments.

\section{In vitro phagocytosis assay}

Primary microglial cells were plated in divided dishes (35 mm, four compartments; Greiner Bio-One, Monroe, NC) for $48 \mathrm{~h}$ at a density of 60,000 cells per well in DMEM with $10 \%$ FBS. Latex beads $(6 \mu \mathrm{m}$, internally dyed with the fluorophore flash green; Polysciences, Inc., Warrington, PA) were preopsonized in $50 \% \mathrm{FBS}$ and PBS. Cells were pretreated with SFHb $(1 \mathrm{mM})$ or vehicle for $2 \mathrm{~h}$. Microglial cell media were then replaced with DMEM alone, and preopsonized beads were added to the cells at a concentration of 10 beads per cell. Microglial cells and beads were incubated at $37^{\circ} \mathrm{C}$ for $1 \mathrm{~h}$ and then subsequently washed with ice-cold PBS. After fixation with $4 \%$ PFA, the images were taken using the EVOS digital inverted fluorescence microscope (Life Technologies, Grand Island, NY).

\section{Statistics}

Data are expressed as mean \pm SEM. Prism 5 software (GraphPad) was used for statistical analysis. In all comparisons, a $P$ value less than 0.05 was considered significant. The statistical comparisons among multiple groups were made by one-way ANOVA followed by NewmanKeuls multiple comparison tests or two-way ANOVA followed by Bonferroni multiple comparison tests, except for neurologic deficit scores, which were calculated by the nonparametric Kruskal-Wallis test followed by Dunn's multiple comparison tests. Differences between two groups were determined by unpaired two-tailed Student's $t$ test.

\section{Results \\ Mortality}

Overall, injection of $10 \mu \mathrm{L}$ of SFHb did not cause any mortality. Of note, we had one mouse die following anesthesia before performing the injection.

\section{Deletion of Hpx and $\mathrm{HO} 2$ aggravates brain injury after SFHb injection}

Our preliminary studies showed that backflow did not occur when mice were injected over a period of $30 \mathrm{~min}$ with $10 \mu \mathrm{L}$ of SFHb. This concentration of $2 \mathrm{mM} \mathrm{SFHb}$ approximates that in whole blood [46]. To define the location and distribution of SFHb, a cohort of mice was injected with 6 or $10 \mu \mathrm{L}$ of SFHb in the right striatum and sacrificed $5 \mathrm{~h}$ after injection. Brain sections revealed 
that the injected $10 \mu \mathrm{L}$ of SFHb diffused to the whole striatum, which led to behavioral disability. This condition was reproducible and optimal to assess the removal capacity of the Hpx-HO2 system (Fig. 1a). Thus, we chose the $10-\mu \mathrm{L}$ injections of SFHb for the following experiments. Cresyl violet staining was used to quantify the lesion volume after injection (Fig. 1b). The results illustrated that $10 \mu \mathrm{L}$ of SFHb led to a lesion in the striatum at $24 \mathrm{~h}$ post-ICH. The $\mathrm{Hpx}^{-1-}$ and $\mathrm{HO}^{-1-}$ mice had larger lesion volume compared to their WT controls $\left(\mathrm{Hpx}^{-/-}, 7.5 \pm 1.4 ; \quad \mathrm{HO}^{-/-}, 7.6 \pm 0.5\right.$ vs. WT, $5.0 \pm$ $0.3 \mathrm{~mm}^{3}$; both $P<0.05$; Fig. 1c). In addition, no obvious lesion was observed in the saline-injected group (data not shown).

\section{Deletion of $\mathrm{Hpx}$ and $\mathrm{HO} 2$ aggravates behavioral deficits after SFHb injection}

At the same time, behavioral tests were performed blindly on the mice until $72 \mathrm{~h}$ after SFHb injection. The data indicated that significant behavioral deficits were caused by injecting $10 \mu \mathrm{L}$ of SFHb in mice. Moreover, deleting $\mathrm{Hpx}$ or $\mathrm{HO} 2$ exerted detrimental effects on the neurological deficit score and undermined the locomotor activities in contrast with their WT controls (Fig. 2b). Further, improved performance on behavioral tests over time suggested that the brain injury caused by injected SFHb was recovering from 24 to $72 \mathrm{~h}$ postinjection (Fig. 2a, b). In addition, the $10-\mu \mathrm{L}$ SFHb injection reduced mouse body weight after surgery; however, this was not significant among genotypes and times (Fig. 2c).

\section{Deletion of Hpx and $\mathrm{HO} 2$ causes more iron deposition and neuronal degeneration}

It has been reported that the accumulated ferric iron after $\mathrm{ICH}$ produced oxidative stress and loss of neurons
[9]. To show whether the toxic iron deposition resulted in neuronal degeneration at $24 \mathrm{~h}$ postinjection, we performed Perls' iron and Fluoro-Jade B staining on a series of sections. Interestingly, we found that the two positively stained signals were colocalized on successive sections (Fig. 3a), supporting that iron overload contributes to neuronal degeneration after ICH. Quantitative results demonstrated that $\mathrm{HO}^{-/-}$mice have a larger Perls' iron-positive area compared to WT controls after SFHb injection (Fig. 3b). Under light microscopy, we observed two types of Perls' iron staining: one was diffused and located in the lesion area, which is generally colocalized with the dense positive signals of Fluoro-Jade B, and the other was located inside glia-like cells (Fig. 3a). To better identify the cell type with iron accumulation, we performed the Perls' iron staining with various cellular markers: Iba1 for microglial cells, GFAP for astrocytes, and NeuN for neurons. The results showed that the Perls' iron-positive signals were mainly in microglial cells (Fig. 3c), suggesting that microglia would appear to be the main cells for heme clearance after ICH. However, the extracellular diffused irons are toxic and cause neuronal degeneration after $\mathrm{ICH}$. It has been reported that macrophages recycle iron in the liver, spleen, and bone marrow [51]. A recent publication reported that proliferation of local resident microglia rather than recruitment of circulating myeloid cells would be the main source of microgliosis after stroke [52]. Our data are overall consistent with such observation, although we could not entirely exclude the role of infiltrating macrophages.

To further address the effects of $\mathrm{Hpx}$ or $\mathrm{HO} 2$ deletion on neuronal degeneration and iron overload, we then quantified the Fluoro-Jade B-positive neuronal cells and the Perls' iron-positive microglial cells around the lesion $24 \mathrm{~h}$ postinjection (Fig. 3d). Compared to the WT
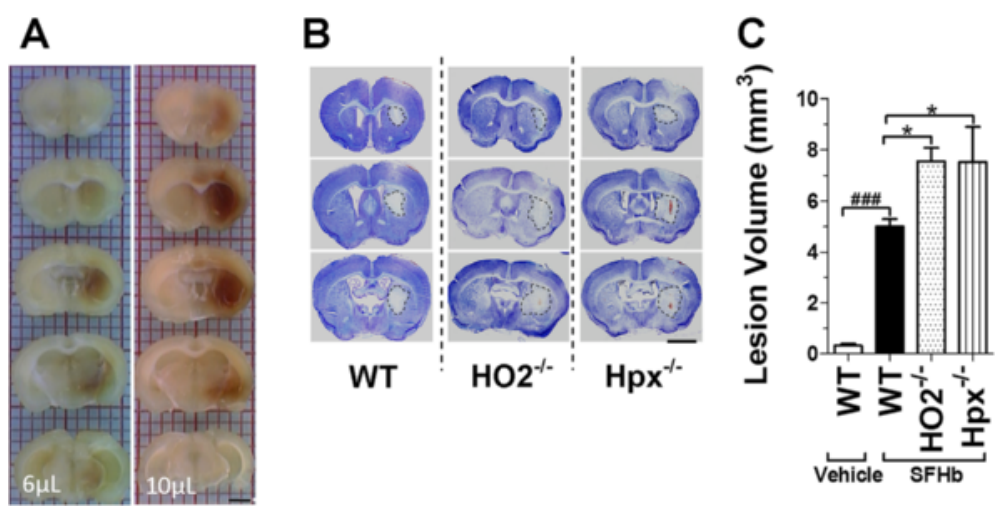

Fig. 1 Deleting Hpx and $\mathrm{HO} 2$ aggravates brain injury after SFHb injection. Photographs on the left are representative brain coronal sections without staining from WT mice illustrating the location of released hemoglobin $5 \mathrm{~h}$ after injection with 6 or $10 \mu \mathrm{L}$ of SFHb (a). A separate cohort of age- and weight-matched $\mathrm{WT}, \mathrm{HO}^{-1-}$, and $\mathrm{Hpx}^{-1-}$ male mice were injected in the striatum with $10 \mu \mathrm{L}$ of SFHb; brains were then sectioned and stained with cresyl violet $24 \mathrm{~h}$ after injection. The lesion perimeter is showed with a dotted line (b). The quantitative analysis shows that $\mathrm{HO}^{-/}$ and $\mathrm{Hpx}^{-1-}$ mice have markedly larger lesion volume than the WT mice (c). Scale bar, $2 \mathrm{~mm}$. Values represent means \pm SEM. ${ }^{*} P<0.05$, \#\#\# $P<0.001$ compared to WT mice, one-way ANOVA followed by Newman-Keuls multiple comparison tests $(n=5-6)$ 

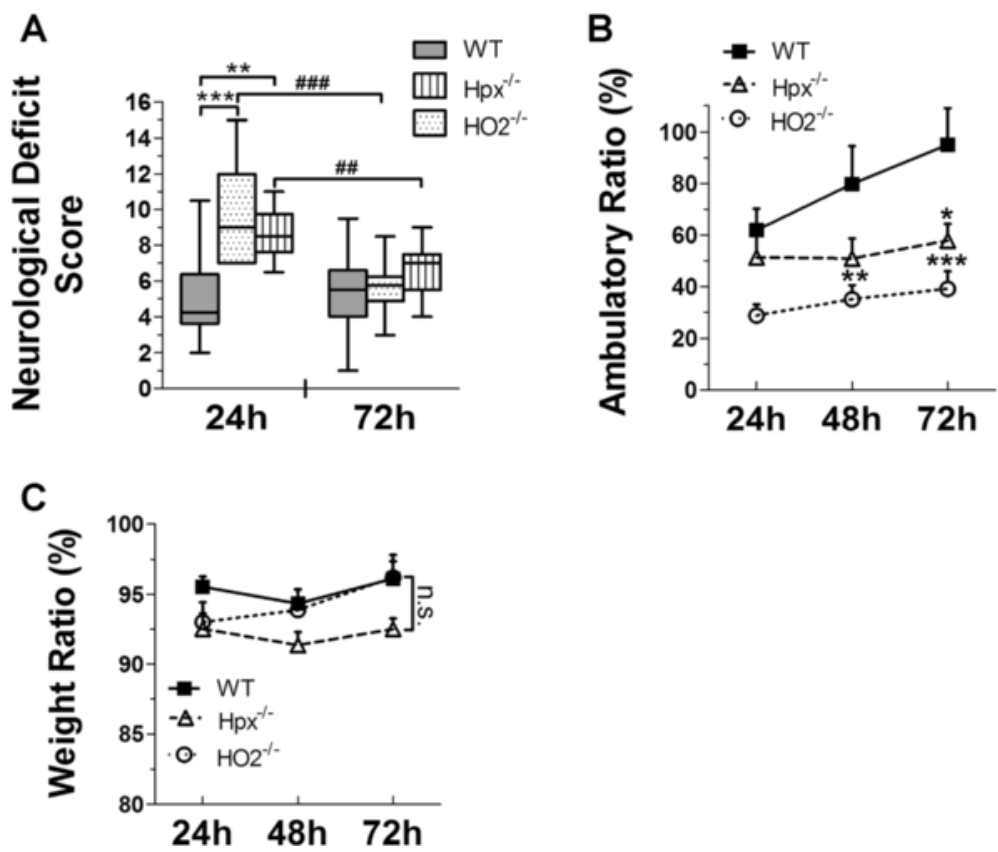

Fig. 2 Deleting Hpx and HO2 aggravates behavioral deficits after SFHb injection. Following SFHb injection, an investigator blind to the genotype assessed neurological function with neurological deficit score (a) and locomotor activity tests (b). All the mice showed recovery from the SFHbinduced injury 24 to $72 \mathrm{~h}$ after injection. The neurological deficit scores of $\mathrm{HO}^{-/-}$and $\mathrm{Hpx}^{-/-}$mice are markedly higher than WTcontrols at $24 \mathrm{~h}$, which suggests that neurological deficits were more severe in $\mathrm{HO}^{-/-}$and $\mathrm{Hpx}^{-/-}$mice (a). In the locomotor test, the ambulatory distance of $\mathrm{HO}^{-1-}$ and $\mathrm{Hpx}^{-1-}$ mice was significantly decreased compared with WT controls $72 \mathrm{~h}$ after injection (b). The body weight of all mice was decreased due to surgery; however, there was no significant difference among different genotypes after injection (c). Values represent means \pm SEM, $n=10-12$ per group. ${ }^{*} P<0.05,{ }^{* *} P<0.01$, ${ }^{* * *} P<0.001$ compared to WT mice; ${ }^{\# \#} P<0.01$, \#\# $P<0.001$ compared to 72 h, one-way or two-way ANOVA followed by Newman-Keuls or Bonferroni comparison tests except for neurological deficit scores, which were calculated by the nonparametric Kruskal-Wallis test followed by Dunn's multiple comparison test

controls, it was shown that $\mathrm{Hpx}^{-/-}$and $\mathrm{HO}^{-/-}$mice had more degenerating neurons $\left(\mathrm{Hpx}^{-/-}, 455 \pm 36\right.$; $\mathrm{HO} 2$ ${ }^{-/-}, 486 \pm 23$ vs. WT, $318 \pm 34$ cells $/ \mathrm{mm}^{2}$; both $P<0.01$; Fig. 3e) and Perls' iron-positive cells $\left(\mathrm{Hpx}^{-/-}, 1394 \pm\right.$ 109; $\mathrm{HO}^{-/-}, 1532 \pm 110$ vs. WT, $788 \pm 69$ cells $/ \mathrm{mm}^{2}$; both $P<0.001$; Fig. 3f). Therefore, we concluded that the resident microglial cells in the brain are actively involved in removing iron products after ICH. However, deleting $\mathrm{Hpx}$ and $\mathrm{HO} 2$ could attenuate this ability because of resultant iron overload in microglia, as indicated by Perls' staining.

\section{Deletion of $\mathrm{Hpx}$ and $\mathrm{HO} 2$ reduces activated microglia after SFHb injection}

It is known that microglia can be activated to exert migration and phagocytosis. We and others have postulated that activated microglial cells could play the critical role in hemoglobin clearance after ICH [38, 47]. However, activated microglia also release proinflammatory factors and reactive oxygen species, which can cause neuronal toxicity. Therefore, it is intriguing to check the net effect of microglial activation in this context of SFHb injection. Iba1 is widely accepted as a marker to show the resting and activated microglial cells in the brain, with an increased expression level during activation. To assess the effects of Hpx or HO2 knockout on microglial activation, we immunostained brain sections with Iba1 antibody to observe microglial activation/morphology around the lesion 24 and $72 \mathrm{~h}$ after SFHb injection (Fig. 4a). The injected SFHb was able to induce microglial activation, and the quantitative data showed that $\mathrm{Hpx}^{-/-}$and $\mathrm{HO}^{-/-}$mice had much less Iba1-positive cells around the lesion compared to WT controls at $24 \mathrm{~h}$ $\left(\mathrm{Hpx}^{-/-}, 476 \pm 62, \mathrm{P}<0.05 ; \mathrm{HO}^{-/-}, 220 \pm 48, P<0.001\right.$ vs. WT, $704 \pm 34$ cells $/ \mathrm{mm}^{2}$ ) and $72 \mathrm{~h}$ postinjection $\left(\mathrm{Hpx}^{-/-} ; 640 \pm 41, \mathrm{P}>0.05 ; \mathrm{HO}^{-/-} ; 416 \pm 46, P<0.01\right.$ vs. WT; $758 \pm 95$ cells $/ \mathrm{mm}^{2}$; Fig. 4b), suggesting that iron deposition within microglial cells could potentially reduce the Iba1 expression level after SFHb injection. Additionally, the numbers of activated microglial cells were increasing from 24 to $72 \mathrm{~h}$ postinjection, especially in $\mathrm{Hpx}^{-1-}$ mice (from $476 \pm 62$ to $640 \pm 41$ cells/ $\mathrm{mm}^{2} ; P<0.05$ ) and $\mathrm{HO}^{-/-}$mice (from $220 \pm 48$ to $416 \pm 46$ cells $/ \mathrm{mm}^{2} ; P<0.05$; Fig. $\left.4 \mathrm{~b}\right)$, which was accompanied with the improvement of behavioral tests during the same time period. Therefore, these results support that microglia could play a net protective role in this SFHb-injection ICH model. 

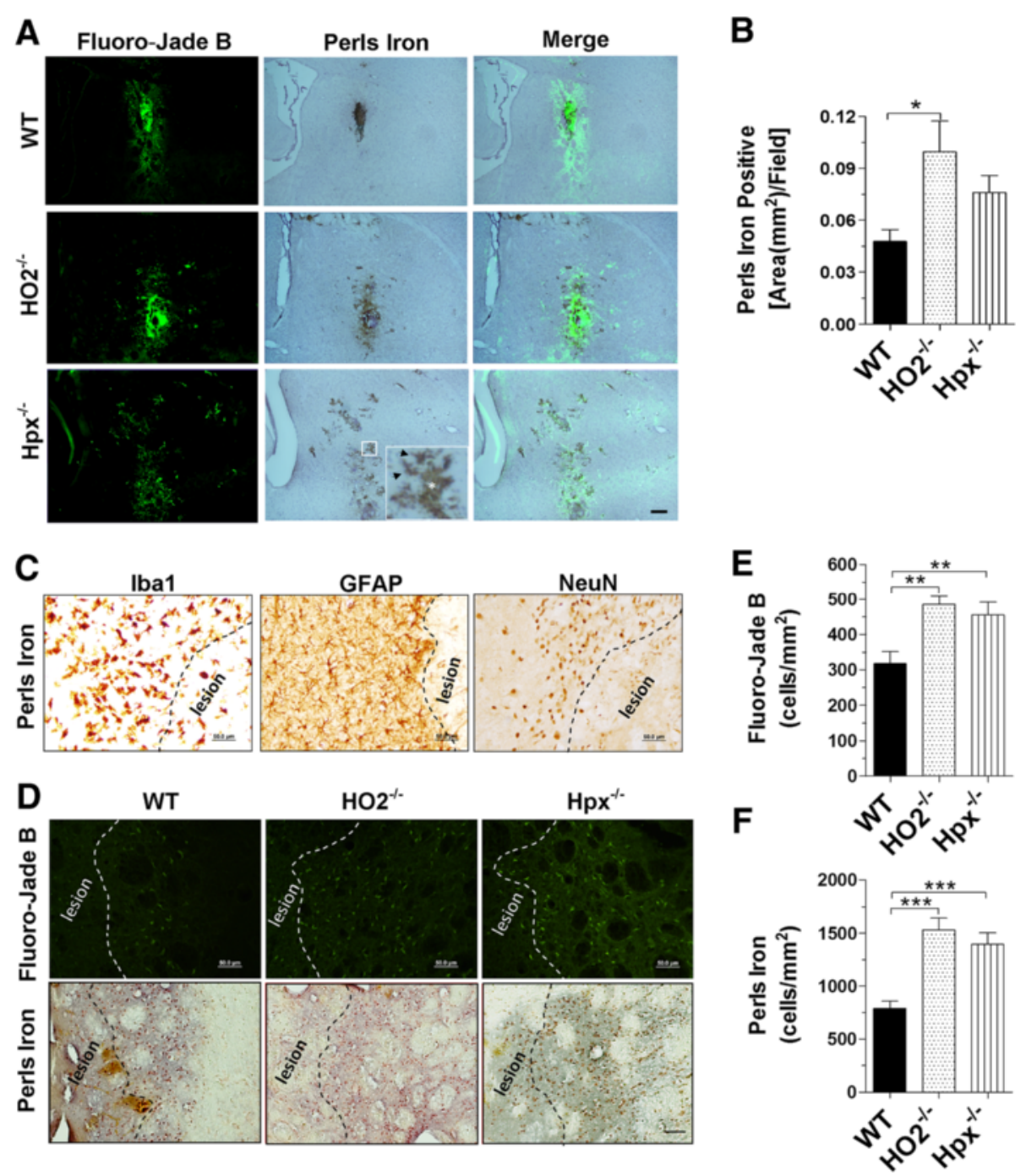

Fig. 3 Iron deposition causes neuronal degeneration. Age- and weight-matched $\mathrm{WT}, \mathrm{HO}^{-1-}$, and $\mathrm{Hpx}^{-1-}$ male mice were injected with $10 \mu \mathrm{L}$ of SFHb, and brains were sectioned and stained with Fluoro-Jade B and Perls' iron staining $24 \mathrm{~h}$ after injection, respectively. Under microscopy, the positive signals of Fluoro-Jade B and Perls' iron staining were colocalized partially on continuous neighbor sections. The inset image shows that glia-like cells (arrow head) were activated around the lesion area (star). Scale bar, $200 \mu \mathrm{m}$ (a). Quantitative data demonstrated that $\mathrm{HO}^{-1-}$ mice have a larger Perls' iron-positive area compared to WT controls after injection (b). Representative images were shown of the Perls' iron staining (blue) with various cellular markers (brown): Iba1 for microglial cells, GFAP for astrocytes, and NeuN for neurons, which illustrated that the Perls' iron-positive signals were mainly in microglial cells. Scale bar, 50 mm (c). The degenerating neurons and Perls' iron-positive cells are shown in coronal sections. Scale bar, $50 \mu \mathrm{m}$ (d). The 10- $\mu \mathrm{L}$ SFHb injection produced significantly more degenerating neurons (e) and Perls' iron-positive microglial cells (f) in $\mathrm{HO}^{-1-}$ and $\mathrm{Hpx}^{-1-}$ mice than those in WT controls. Values represent means $\pm \mathrm{SEM} .{ }^{*} P<0.05$, ${ }^{* *} P<0.01$, and ${ }^{* * *} P<0.001$, compared to WT mice, one-way ANOVA followed by Newman-Keuls multiple comparison tests $(n=5-6)$

\section{Hemoglobin treatment induces iron deposition and reduces Iba1 expression}

To further address whether microglial cells take up heme-hemoglobin and contribute to hemoglobin clearance, we treated cultured primarily microglial cells with two doses of SFHb for $2 \mathrm{~h}$ and then performed the Perls' iron and Iba1 double staining (Fig. 5a). First, we confirmed that hemoglobin can induce microglial activation. The areas of microglial cells treated with SFHb were markedly bigger than vehicle-treated cells (Fig. 5b).
Second, it was observed that SFHb treatment significantly increased the amount of iron accumulated in microglia and that higher SFHb treatment dosage resulted in more iron deposition within microglial cells (Fig. 5c). Further, we found that the accumulated iron in microglia reduced the Iba1 expression level, illustrating a significant negative correlation by linearregression analysis (Fig. 5d). This observation supports our in vivo data that the injected SFHb may either directly or indirectly decrease the Iba1 


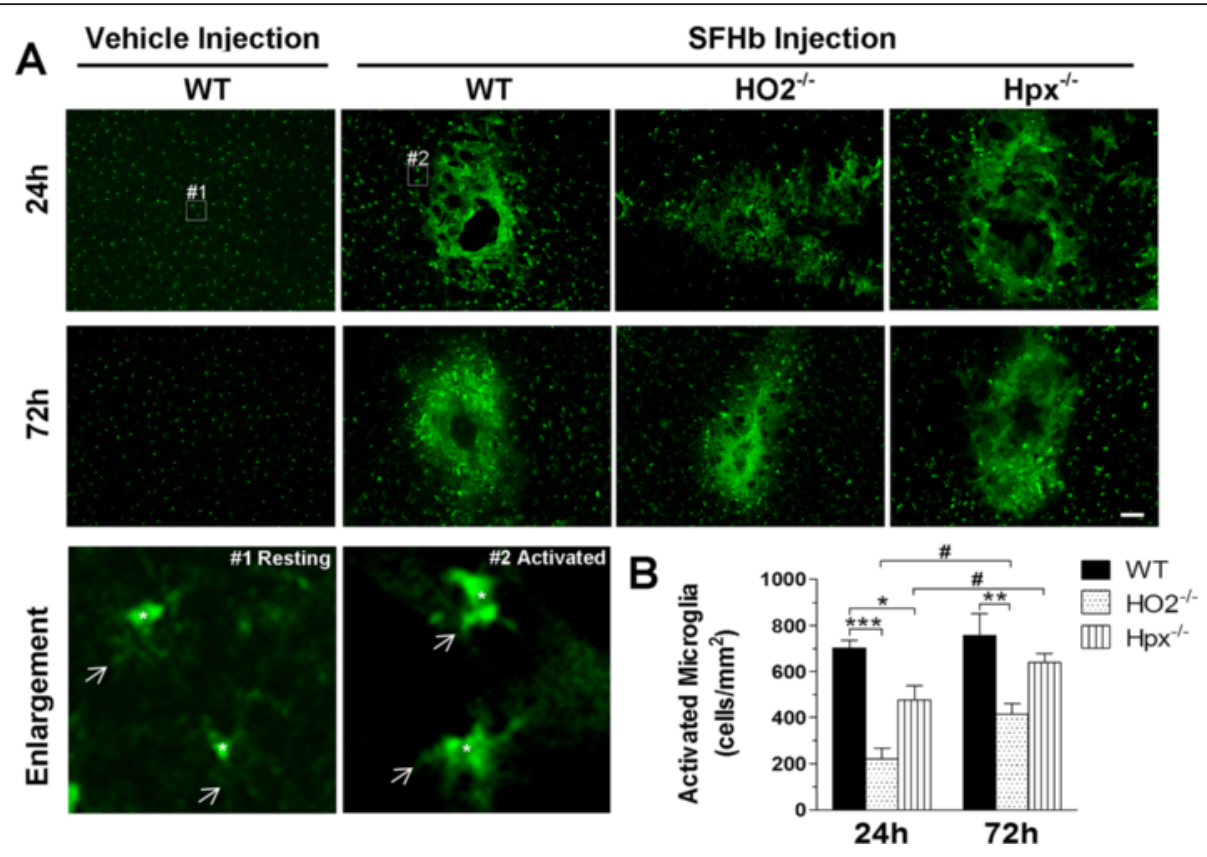

Fig. 4 Deleting Hpx and HO2 reduces activated microglia. The distribution and morphology of microglia (lba1 positive) can be seen in coronal sections collected at 24 and $72 \mathrm{~h}$ from WT and $\mathrm{Hpx}^{-1-}$ mice (a). Activated microglial cells were observed in and around the injury region after the SFHb injection (\#2, with large cell bodies bearing short and thick processes) in contrast with resting microglia in the vehicle group (\#1, with small cell bodies bearing ramified long and fine processes). Stars indicate cell bodies and arrows present cell processes. Quantitative analysis demonstrated that $\mathrm{HO}^{-/-}$and $\mathrm{Hpx}^{-1-}$ mice had less activated microglia at 24 and $72 \mathrm{~h}$ than WT mice. In addition, $72 \mathrm{~h}$ after injection, their activated microglia cells were significantly increased compared with those at $24 \mathrm{~h}$ (b). Scale bar, $50 \mu \mathrm{m}$; values represent means $\pm S E M$. ${ }^{*} P<0.05$, ${ }^{* *} P<0.01$, and ${ }^{* * *} P<0.001$, compared to WT mice; \#P $<0.05$ compared to 72 h, one-way or two-way ANOVA followed by Newman-Keuls or Bonferroni comparison tests $(n=5-6)$

expression level and concurrently change Iba1-positive microglia to Perls' iron-positive microglia.

\section{Hemoglobin treatment inhibits microglial phagocytosis}

Iba1 is known to play an important role in microglia migration and phagocytosis $[53,54]$. To determine the effect of iron overload on microglial phagocytosis, we treated primary microglial cells with SFHb (1 mM) or vehicle for $2 \mathrm{~h}$ and then incubated them with fluorescent latex beads for $1 \mathrm{~h}$ (Fig. 6a). The results showed that the hemoglobin pretreatment markedly reduced the percentage of phagocytic microglial cells (Fig. 6b) and the numbers of beads attached by microglia (Fig. 6c). This may suggest that following $\mathrm{ICH}$, hemoglobin degradation within cells would affect microglial phagocytosis and delay resultant hematoma removal.

\section{Discussion}

By using the 10- $\mu \mathrm{L}$ SFHb-injection model, we found that $\mathrm{Hpx}$ or $\mathrm{HO} 2$ deletion leads to aggravated brain injury and Perls' iron deposition, which was consistent with the behavioral results showing the neurological and locomotor disability of the $\mathrm{Hpx}^{-/-}$and $\mathrm{HO}^{-/-}$mice. Furthermore, by performing double staining of Perls' iron with various cellular markers, we showed that the Perls' iron-positive cells were mainly Iba1-positive microglial cells. Using mouse primary microglial cultures, we also observed that the SFHb dose-dependently increased Perls' iron deposition within these cells and, interestingly, iron accumulation appeared to negatively correlate with Iba1 staining. Finally, using similar cultures, we observed that the rate of beads being phagocytosed within SFHb-treated microglia was drastically attenuated. These data suggest that (a) microglial cells contribute to hemoglobin-heme clearance after ICH; (b) however, the resultant heme/iron overloads in microglia appears to decrease Iba1 expression and further inhibit microglial phagocytosis. Therefore, microglial cells may have a sort of threshold for their hemoglobin-heme degradative capacity. Above this level, their activity, such as phagocytosis, is severely compromised.

The disparate effects of $\mathrm{HO} 2$ knockout have been shown in whole-blood and collagenase-injection models, which indicate the complexity in rodent $\mathrm{ICH}$ models and the necessity of a simplified ICH model $[55,56]$. Here, in the $10-\mu \mathrm{L}$ SFHb-injection model, the hemoglobin diffuses throughout the mouse striatum and produces a gradient distribution to induce the activation of microglia, which could be optimal to evaluate the hemoglobinremoval capacity of the $\mathrm{Hpx}-\mathrm{HO}$ system. Also, hemoglobin injection excludes the intrinsic inflammatory influence of the erythrocyte debris and recombinant 

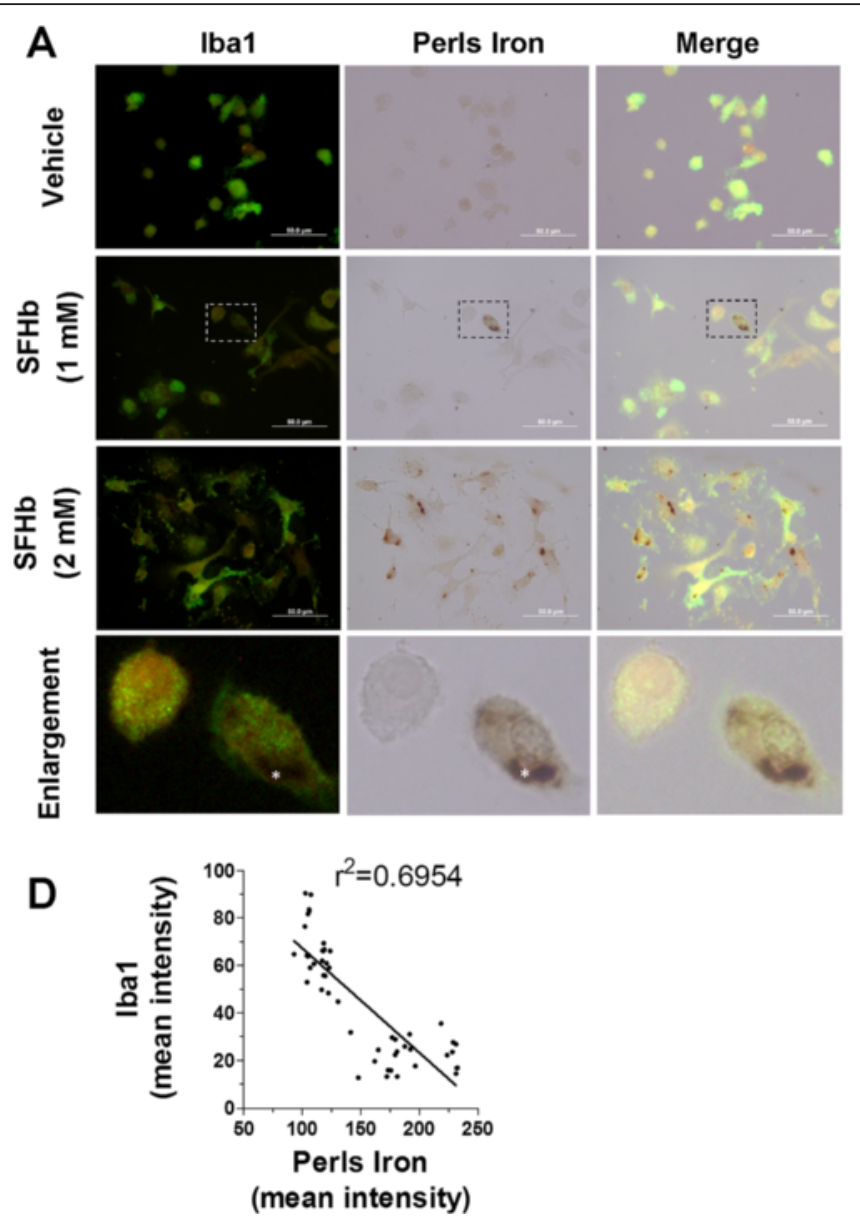

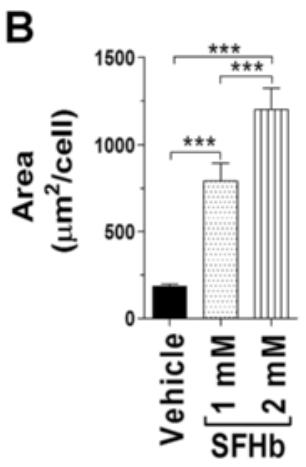

C

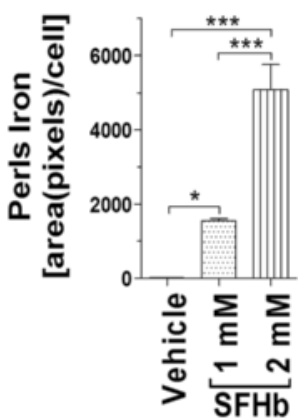

Fig. 5 Hemoglobin treatment induces iron deposition and reduces Iba1 expression. The primary microglia derived from WT mice were treated with $\mathrm{SFHb}$ for $2 \mathrm{~h}$ as indicated concentration. Distribution of Iba1 (green) and iron localization (black) was shown in microglia by double staining. The cells highlighted within the dashed box were demonstrated at a higher magnification in the enlargement. The asterisk (*) indicates that lba1 signals were absent at the Perls' iron-positive area (a). The bar graph shows the significant changes in the size of microglia that are Perls' iron-positive. SFHb treatment greatly increases microglial size, which is dose-dependent (b). The SFHb-treated microglial cells have a larger area of positive Perls' iron staining, suggesting SFHb-induced iron deposition inside microglia (c). The linear-regression graph illustrates that Perls' iron-positive signals are negatively related to Iba1-positive signals, $n \geq 50$ cells (d). Scale bar, $50 \mu \mathrm{m}$. Values represent means \pm SEM. Significant differences between the groups are expressed as follows: ${ }^{*} P<0.05$; ${ }^{* * *} P<0.001$, one-way ANOVA followed by Newman-Keuls multiple comparison tests. The experiment was repeated three times and in $n \geq 150$ cells

collagenase in whole-blood and collagenase-injection models. In our preliminary test, we had confirmed that minimal backflow happened over a very slow 30-min period of injection before withdrawing the needle. In addition, Hpx-deficient mice are viable and fertile [44]. Nevertheless, $\mathrm{Hpx}^{-1-}$ mice were shown having iron deposits in oligodendrocytes $[57,58]$. The Hp protein and mRNA levels are comparable in serum between naïve $\mathrm{Hpx}^{-1-}$ and WT mice; however, after hemolytic stimulus, $\mathrm{Hpx}^{-1-}$ mice showed persisted Hp levels in the circulation, suggesting compensatory expression of $\mathrm{Hp}$ induced by hemolysis [44]. It is well known that iron reacts with lipid hydroperoxides to produce free radicals. Free radicals attack DNA, lipids, and proteins, causing oxidative brain injury. In this study, the degradation of the injected SFHb caused two types of iron deposition in brain tissues: one appearing to be intensely diffused iron deposition in the lesion area and the other suggested to be iron overload in microglial cells. The results demonstrated that the distribution of Perls' iron staining was consistent with that of neuronal degeneration shown by Fluoro-Jade B staining, which suggested that iron overload mainly contributes to neuronal degeneration after SFHb injection. Under microscopy, we found that the Perls' iron-positive cells that were glia-like migrated around the lesion area. To further determine which cell type mainly contributes to this hemoglobin clearance and cellular iron accumulation around lesions, we performed double staining of various cellular markers with Perls' iron and showed that microglia mainly contribute to the clearance of hemoglobin 

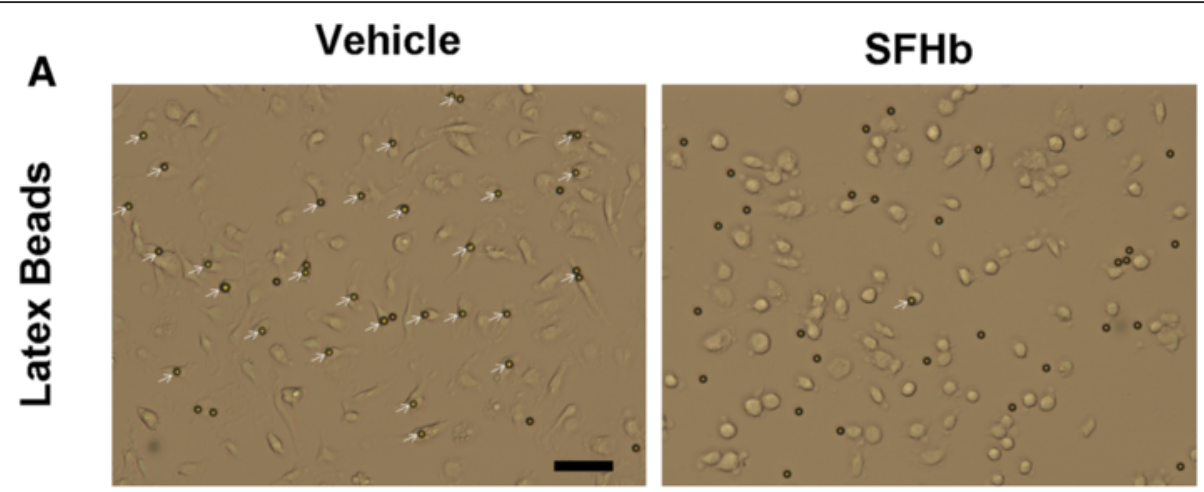

B

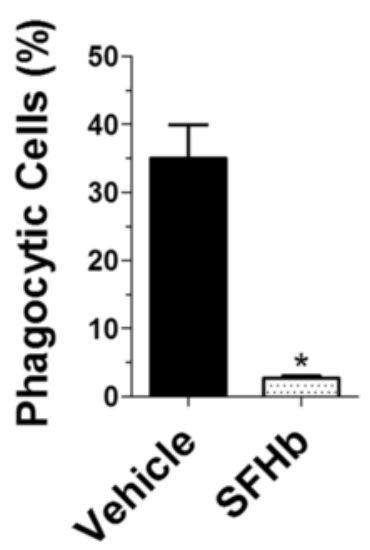

C

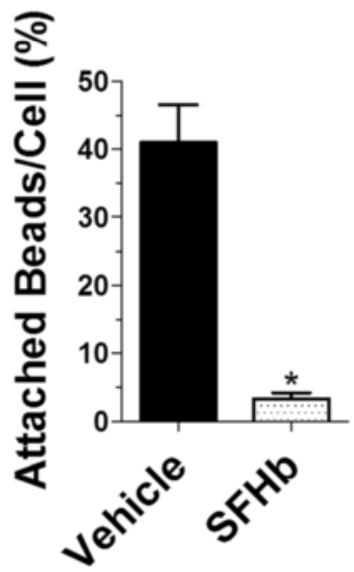

Fig. 6 Hemoglobin treatment inhibits microglial phagocytosis. Primary microglial cells were treated with SFHb (1 mM) or vehicle for $2 \mathrm{~h}$ and then incubated with fluorescent latex beads (diameter $6 \mu \mathrm{m}$ ) for $1 \mathrm{~h}$. Representative images were taken and white arrows illustrate the attached beads to microglial cells (a). Bar graphs show that the hemoglobin pretreatment markedly reduces the percentage of phagocytic microglial cells (b) and the numbers of attached beads (c). Scale bar, $50 \mu \mathrm{m}$. Values represent means \pm SEM. Differences between two groups were determined by unpaired two-tailed Student's $t$ test. The experiment was repeated three times and in $n \geq 150$ cells

after ICH. This result was supported by the study from Keep's group [59], and it was also reported by Koeppen's group that most iron-positive cells around intracerebral hematoma were microglia [60].

It could be concluded that whether activated microglia exert protective or toxic effects might be context dependent, determined by both injury severity and duration [61, 62]. For example, the exogenous application of microglia was shown to protect against different types of ischemic injury in vivo [63-65] and in vitro [40]. On the other hand, brain microglial activation and its related inflammatory response had been shown to confer neurotoxicity in various models of neurodegeneration [66-69]. In this SFHb-injection model, compared to the toxicity of the large amount of hemoglobin, the harmful effects of the proinflammatory cytokines released from the activated microglial cells might remain minor within the experimental time frame and the beneficial potential of the neuroprotective factors might be limited. Therefore, we suggest that under our experimental protocol, it was the effect of microglial phagocytosis that contributed to hemoglobin/heme clearance and behavioral improvement over time.

An interesting observation here was the suggestion that the iron overload appeared to reduce the Iba1 expression level, which could lead to reduced microglial phagocytosis. Also, it may be the reason why more Perls' iron-positive staining microglia were accompanied with less Iba1-positive microglia around the lesion area in $\mathrm{HO}^{-/-}$and $\mathrm{Hpx}^{-/-}$mice. As mentioned, Iba1 proteins have been described as playing an essential role in microglia migration and phagocytosis $[53,70]$. Thus, we speculate that the effect of $\mathrm{HO} 2$ deletion may be increasing the vulnerability of microglia to hemoglobin, potentially similar to the effect already reported for $\mathrm{HO} 1$ deficiency [71]. $\mathrm{Hpx}^{-/-}$mice could change the way heme was delivered to microglia and neurons from a controlled, receptor-based mechanism to uncontrolled intercalation into membranes and subsequent oxidative injury. Thus, it was not entirely surprising that it would 
result in a deleterious effect on microglia and neurons, while increasing iron staining.

\section{Conclusions}

Our findings suggest that microglial cells contribute to hemoglobin-heme clearance after $\mathrm{ICH}$; however, the resultant iron overloads in microglia appear to decrease Iba1 expression and further inhibit microglial phagocytosis that warrants further investigation.

\begin{abstract}
Abbreviations
DAB: 3,3'-diaminobenzidine; DMEM: Dulbecco's modified Eagle's medium; FBS: fetal bovine serum; GFAP: glial fibrillary acidic protein; $\mathrm{HO}$ : heme oxygenase; $\mathrm{HO} 2$ : heme oxygenase 2; $\mathrm{HO}^{-1-}$ : $\mathrm{HO} 2$ knockout; Hpx: hemopexin; $\mathrm{Hpx}^{-/-}$: Hpx knockout; Iba1: ionized calcium-binding adapter protein 1; ICH: intracerebral hemorrhage; PBS: phosphate-buffered saline; PFA: paraformaldehyde; SFHb: stroma-free hemoglobin; WT: wild type.
\end{abstract}

\section{Competing interests}

The authors declare that they have no competing interests.

\section{Authors' contributions}

B.M. contributed to the study design, in vivo and in vitro experiments, data analyses, interpretation of results, and writing of the manuscript; J.D., H.P., and B.S. contributed to the Perls' staining, data quantification, in vivo and in vitro experiments, and reviewing of the manuscript; E.T. contributed to the development of the $\mathrm{Hpx}^{-/-}$mice and reviewed the manuscript; S.D. contributed to the study design, interpretation of results, and writing and revision of the manuscript. All authors have read and approved the manuscript for publication.

\section{Acknowledgements}

This study was supported in part by grants from the National Institute of Health NS046400 (S.D.) and an American Heart and Stroke Association grant POST2080364 (B.M.)

\section{Author details \\ 'Department of Anesthesiology, Center for Translational Research in Neurodegenerative Disease, University of Florida College of Medicine, P.O. Box 100159, Gainesville, FL 32610, USA. ²Departments of Molecular Biotechnology and Health Sciences, University of Torino, Torino, Italy. ${ }^{3}$ Departments of Neuroscience, Neurology, Psychiatry, Psychology and Pharmaceutics, University of Florida College of Medicine, Gainesville, FL 32610, USA.}

Received: 5 May 2015 Accepted: 23 January 2016

Published online: 01 February 2016

\section{References}

1. Donnan GA, Hankey GJ, Davis SM. Intracerebral haemorrhage: a need for more data and new research directions. Lancet Neurol. 2010:9:133-4.

2. Umbreit J. Methemoglobin-it's not just blue: a concise review. Am J Hematol. 2007:82:134-44.

3. Jeney V, Balla J, Yachie A, Varga Z, Vercellotti GM, Eaton JW, et al. Prooxidant and cytotoxic effects of circulating heme. Blood. 2002;100:879-87.

4. Bunn HF, Jandl JH. Exchange of heme among hemoglobins and between hemoglobin and albumin. J Biol Chem. 1968;243:465-75.

5. Pohlman TH, Harlan JM. Adaptive responses of the endothelium to stress. J Surg Res. 2000;89:85-119.

6. Balla J, Jacob HS, Balla G, Nath K, Eaton JW, Vercellotti GM. Endothelial-cell heme uptake from heme proteins: induction of sensitization and desensitization to oxidant damage. Proc Natl Acad Sci U S A. 1993:90:9285-9.

7. Wagener FA, Eggert A, Boerman OC, Oyen WJ, Verhofstad A, Abraham NG, et al. Heme is a potent inducer of inflammation in mice and is counteracted by heme oxygenase. Blood. 2001;98:1802-11.

8. Paoli M, Marles-Wright J, Smith A. Structure-function relationships in heme-proteins. DNA Cell Biol. 2002;21:271-80.
9. Wagner KR, Sharp FR, Ardizzone TD, Lu A, Clark JF. Heme and iron metabolism: role in cerebral hemorrhage. J Cereb Blood Flow Metab. 2003;23:629-52

10. Grinshtein N, Bamm W, Tsemakhovich VA, Shaklai N. Mechanism of lowdensity lipoprotein oxidation by hemoglobin-derived iron. Biochemistry. 2003:42:6977-85.

11. Belcher JD, Beckman JD, Balla G, Balla J, Vercellotti G. Heme degradation and vascular injury. Antioxid Redox Signal. 2010;12:233-48.

12. Aronowski J, Zhao X. Molecular pathophysiology of cerebral hemorrhage: secondary brain injury. Stroke. 2011;42:1781-6.

13. Tolosano E, Altruda F. Hemopexin: structure, function, and regulation. DNA Cell Biol. 2002;21:297-306.

14. Deuel JW, Vallelian F, Schaer CA, Puglia M, Buehler PW, Schaer DJ. Different target specificities of haptoglobin and hemopexin define a sequential protection system against vascular hemoglobin toxicity. Free Radic Biol Med. 2015:89:931

15. Buehler PW, Abraham B, Vallelian F, Linnemayr C, Pereira CP, Cipollo JF, et al. Haptoglobin preserves the CD163 hemoglobin scavenger pathway by shielding hemoglobin from peroxidative modification. Blood. 2009;113:2578-86

16. Gutteridge JM, Smith A. Antioxidant protection by haemopexin of haemstimulated lipid peroxidation. Biochem J. 1988;256:861-5.

17. Hvidberg V, Maniecki MB, Jacobsen C, Hojrup P, Moller HJ, Moestrup SK. Identification of the receptor scavenging hemopexin-heme complexes. Blood. 2005;106:2572-9.

18. Williams KR, Saunders AM, Roses AD, Armati PJ. Uptake and internalization of exogenous apolipoprotein E3 by cultured human central nervous system neurons. Neurobiol Dis. 1998:5:271-9.

19. Borda JT, Alvarez X, Mohan M, Hasegawa A, Bernardino A, Jean S, et al. CD163, a marker of perivascular macrophages, is up-regulated by microglia in simian immunodeficiency virus encephalitis after haptoglobinhemoglobin complex stimulation and is suggestive of breakdown of the blood-brain barrier. Am J Pathol. 2008;172:725-37.

20. Zhao X, Song S, Sun G, Strong R, Zhang J, Grotta JC, et al. Neuroprotective role of haptoglobin after intracerebral hemorrhage. J Neurosci. 2009:29:15819-27.

21. Li RC, Saleem S, Zhen G, Cao W, Zhuang H, Lee J, et al. Heme-hemopexin complex attenuates neuronal cell death and stroke damage. J Cereb Blood Flow Metab. 2009;29:953-64.

22. Sutherland BA, Rahman RM, Clarkson AN, Shaw OM, Nair SM, Appleton I. Cerebral heme oxygenase 1 and 2 spatial distribution is modulated following injury from hypoxia-ischemia and middle cerebral artery occlusion in rats. Neurosci Res. 2009:65:326-34.

23. Morris CM, Candy JM, Edwardson JA, Bloxham CA, Smith A. Evidence for the localization of haemopexin immunoreactivity in neurones in the human brain. Neurosci Lett. 1993;149:141-4.

24. Dwyer BE, Nishimura RN, Lu SY. Differential expression of heme oxygenase1 in cultured cortical neurons and astrocytes determined by the aid of a new heme oxygenase antibody. Response to oxidative stress. Brain Res Mol Brain Res. 1995;30:37-47

25. Fukuda K, Panter SS, Sharp FR, Noble LJ. Induction of heme oxygenase-1 (HO-1) after traumatic brain injury in the rat. Neurosci Lett. 1995;199:127-30.

26. Matz PG, Weinstein PR, Sharp FR. Heme oxygenase-1 and heat shock protein 70 induction in glia and neurons throughout rat brain after experimental intracerebral hemorrhage. Neurosurgery. 1997:40:152-60.

27. Zakhary R, Gaine SP, Dinerman JL, Ruat M, Flavahan NA, Snyder SH. Heme oxygenase 2: endothelial and neuronal localization and role in endothelium-dependent relaxation. Proc Natl Acad Sci U S A. 1996;93:795-8.

28. Zhao H, Wong RJ, Nguyen X, Kalish F, Mizobuchi M, Vreman HJ, et al. Expression and regulation of heme oxygenase isozymes in the developing mouse cortex. Pediatr Res. 2006;60:518-23.

29. Doré S. Decreased activity of the antioxidant heme oxygenase enzyme: implications in ischemia and in Alzheimer's disease. Free Radic Biol Med 2002;32:1276-82.

30. Kim YS, Doré S. Catalytically inactive heme oxygenase-2 mutant is cytoprotective. Free Radic Biol Med. 2005:39:558-64.

31. Scapagnini G, D'Agata V, Calabrese V, Pascale A, Colombrita C, Alkon D, Cavallaro S: Gene expression profiles of heme oxygenase isoforms in the rat brain. Brain research. 2002;954:51-59.

32. Chang EF, Wong RJ, Vreman HJ, Igarashi T, Galo E, Sharp FR, et al. Heme oxygenase-2 protects against lipid peroxidation-mediated cell loss and 
impaired motor recovery after traumatic brain injury. J Neurosci. 2003;23:3689-96

33. McCoubrey Jr WK, Huang TJ, Maines MD. Heme oxygenase-2 is a hemoprotein and binds heme through heme regulatory motifs that are not involved in heme catalysis. J Biol Chem. 1997;272:12568-74.

34. Yi L, Jenkins PM, Leichert LI, Jakob U, Martens JR, Ragsdale SW. Heme regulatory motifs in heme oxygenase-2 form a thiol/disulfide redox switch that responds to the cellular redox state. J Biol Chem. 2009;284:20556-61.

35. Dore S, Takahashi M, Ferris CD, Zakhary R, Hester LD, Guastella D, et al. Bilirubin, formed by activation of heme oxygenase-2, protects neurons against oxidative stress injury. Proc Natl Acad Sci U S A. 1999;96:2445-50

36. Dore S, Sampei K, Goto S, Alkayed NJ, Guastella D, Blackshaw S, et al. Heme oxygenase-2 is neuroprotective in cerebral ischemia. Mol Med. 1999:5:656-63

37. Maines MD. The heme oxygenase system: a regulator of second messenger gases. Annu Rev Pharmacol Toxicol. 1997;37:517-54.

38. Zhao X, Sun G, Zhang J, Strong R, Song W, Gonzales N, et al. Hematoma resolution as a target for intracerebral hemorrhage treatment: role for peroxisome proliferator-activated receptor gamma in microglia/ macrophages. Ann Neurol. 2007;61:352-62.

39. Streit WJ. Microglia as neuroprotective, immunocompetent cells of the CNS. Glia. 2002:40:133-9.

40. Neumann J, Gunzer M, Gutzeit HO, Ullrich O, Reymann KG, Dinkel K. Microglia provide neuroprotection after ischemia. FASEB J. 2006;20:714-6.

41. Lalancette-Hebert M, Gowing G, Simard A, Weng YC, Kriz J. Selective ablation of proliferating microglial cells exacerbates ischemic injury in the brain. J Neurosci. 2007;27:2596-605

42. Meyer-Luehmann M, Spires-Jones TL, Prada C, Garcia-Alloza M, de Calignon A, Rozkalne A, et al. Rapid appearance and local toxicity of amyloid-beta plaques in a mouse model of Alzheimer's disease. Nature. 2008;451:720-4.

43. Nimmerjahn A, Kirchhoff F, Helmchen F. Resting microglial cells are highly dynamic surveillants of brain parenchyma in vivo. Science. 2005;308:1314-8.

44. Tolosano E, Hirsch E, Patrucco E, Camaschella C, Navone R, Silengo L, et al. Defective recovery and severe renal damage after acute hemolysis in hemopexin-deficient mice. Blood. 1999;94:3906-14.

45. Poss KD, Thomas MJ, Ebralidze AK, O'Dell TJ, Tonegawa S. Hippocampa long-term potentiation is normal in heme oxygenase-2 mutant mice. Neuron. 1995;15:867-73.

46. Qu Y, Chen J, Benvenisti-Zarom L, Ma X, Regan RF. Effect of targeted deletion of the heme oxygenase-2 gene on hemoglobin toxicity in the striatum. J Cereb Blood Flow Metab. 2005;25:1466-75.

47. Singh N, Ma B, Leonardo CC, Ahmad AS, Narumiya S, Doré S. Role of PGE(2) EP1 receptor in intracerebral hemorrhage-induced brain injury. Neurotox Res. 2013;24:549-59.

48. Clark W, Gunion-Rinker L, Lessov N, Hazel K. Citicoline treatment for experimental intracerebral hemorrhage in mice. Stroke. 1998;29:2136-40.

49. Schmued LC, Hopkins KJ. Fluoro-Jade B: a high affinity fluorescent marker for the localization of neuronal degeneration. Brain Res. 2000;874:123-30.

50. Kitagawa H, Sasaki C, Sakai K, Mori A, Mitsumoto Y, Mori T, et al. Adenovirusmediated gene transfer of glial cell line-derived neurotrophic factor prevents ischemic brain injury after transient middle cerebral artery occlusion in rats. J Cereb Blood Flow Metab. 1999;19:1336-44.

51. Knutson M, Wessling-Resnick M. Iron metabolism in the reticuloendothelial system. Crit Rev Biochem Mol Biol. 2003;38:61-88.

52. Li T, Pang S, Yu Y, Wu X, Guo J, Zhang S. Proliferation of parenchymal microglia is the main source of microgliosis after ischaemic stroke. Brain 2013;136:3578-88

53. Ohsawa K, Imai Y, Kanazawa H, Sasaki Y, Kohsaka S. Involvement of Iba1 in membrane ruffling and phagocytosis of macrophages/microglia. J Cell Sci. 2000;113(Pt 17):3073-84

54. Sasaki $Y$, Ohsawa K, Kanazawa H, Kohsaka S, Imai $Y$. Iba1 is an actin-crosslinking protein in macrophages/microglia. Biochem Biophys Res Commun 2001;286:292-7.

55. Qu Y, Chen-Roetling J, Benvenisti-Zarom L, Regan RF. Attenuation of oxidative injury after induction of experimental intracerebral hemorrhage in heme oxygenase-2 knockout mice. J Neurosurg. 2007;106:428-35.

56. Wang J, Doré S. Heme oxygenase 2 deficiency increases brain swelling and inflammation after intracerebral hemorrhage. Neuroscience. 2008;155:1133-41.

57. Morello N, Tonoli E, Logrand F, Fiorito V, Fagoonee S, Turco E, et al. Haemopexin affects iron distribution and ferritin expression in mouse brain. J Cell Mol Med. 2009;13:4192-204.
58. Morello N, Bianchi FT, Marmiroli P, Tonoli E, Rodriguez Menendez V, Silengo $L$, et al. A role for hemopexin in oligodendrocyte differentiation and myelin formation. Plos one. 2011;6:e20173.

59. Wu J, Hua Y, Keep RF, Nakamura T, Hoff JT, Xi G. Iron and iron-handling proteins in the brain after intracerebral hemorrhage. Stroke. 2003;34:2964-9.

60. Koeppen AH, Dickson AC, McEvoy JA. The cellular reactions to experimental intracerebral hemorrhage. J Neurol Sci. 1995;134(Suppl):102-12.

61. Raivich G, Bohatschek M, Kloss CU, Werner A, Jones LL, Kreutzberg GW. Neuroglial activation repertoire in the injured brain: graded response, molecular mechanisms and cues to physiological function. Brain Res Brain Res Rev. 1999:30:77-105.

62. van Rossum D, Hanisch UK. Microglia. Metab Brain Dis. 2004;19:393-411.

63. Kitamura Y, Yanagisawa D, Inden M, Takata K, Tsuchiya D, Kawasaki T, et al. Recovery of focal brain ischemia-induced behavioral dysfunction by intracerebroventricular injection of microglia. J Pharmacol Sci. 2005:97:289-93.

64. Imai F, Suzuki H, Oda J, Ninomiya T, Ono K, Sano H, et al. Neuroprotective effect of exogenous microglia in global brain ischemia. J Cereb Blood Flow Metab. 2007;27:488-500.

65. Yong WW, Rivest $\mathrm{S}$. Taking advantage of the systemic immune system to cure brain diseases. Neuron. 2009;64:55-60.

66. Yrjanheikki J, Tikka T, Keinanen R, Goldsteins G, Chan PH, Koistinaho J. A tetracycline derivative, minocycline, reduces inflammation and protects against focal cerebral ischemia with a wide therapeutic window. Proc Natl Acad Sci U S A. 1999:96:13496-500

67. Tikka T, Fiebich BL, Goldsteins G, Keinanen R, Koistinaho J. Minocycline, a tetracycline derivative, is neuroprotective against excitotoxicity by inhibiting activation and proliferation of microglia. J Neurosci. 2001;21:2580-8.

68. Kriz J, Nguyen MD, Julien JP. Minocycline slows disease progression in a mouse model of amyotrophic lateral sclerosis. Neurobiol Dis. 2002;10:268-78.

69. Kriz J, Gowing G, Julien JP. Efficient three-drug cocktail for disease induced by mutant superoxide dismutase. Ann Neurol. 2003;53:429-36.

70. Imai Y, Kohsaka S. Intracellular signaling in M-CSF-induced microglia activation: role of Iba1. Glia. 2002:40:164-74.

71. Kovtunovych G, Eckhaus MA, Ghosh MC, Ollivierre-Wilson H, Rouault TA. Dysfunction of the heme recycling system in heme oxygenase 1-deficient mice: effects on macrophage viability and tissue iron distribution. Blood. 2010:116:6054-62

\section{Submit your next manuscript to BioMed Central and we will help you at every step:}

- We accept pre-submission inquiries

- Our selector tool helps you to find the most relevant journal

- We provide round the clock customer support

- Convenient online submission

- Thorough peer review

- Inclusion in PubMed and all major indexing services

- Maximum visibility for your research

Submit your manuscript at www.biomedcentral.com/submit
Biomed Central 